\title{
Upaya Optimalisasi Lahan Pekarangan melalui Pelatihan Teknik Budidaya Cabai Rawit Terpadu dan Inisiasi Pembentukan KWT pada Kelompok Hidayah Tani di Jember, Jawa Timur
}

\author{
Optimization of House Garden through Cayenne Pepper Utilization and Initiation \\ Establishment of Hidayah Tani Women Farmers Group in Jember, East Java
}

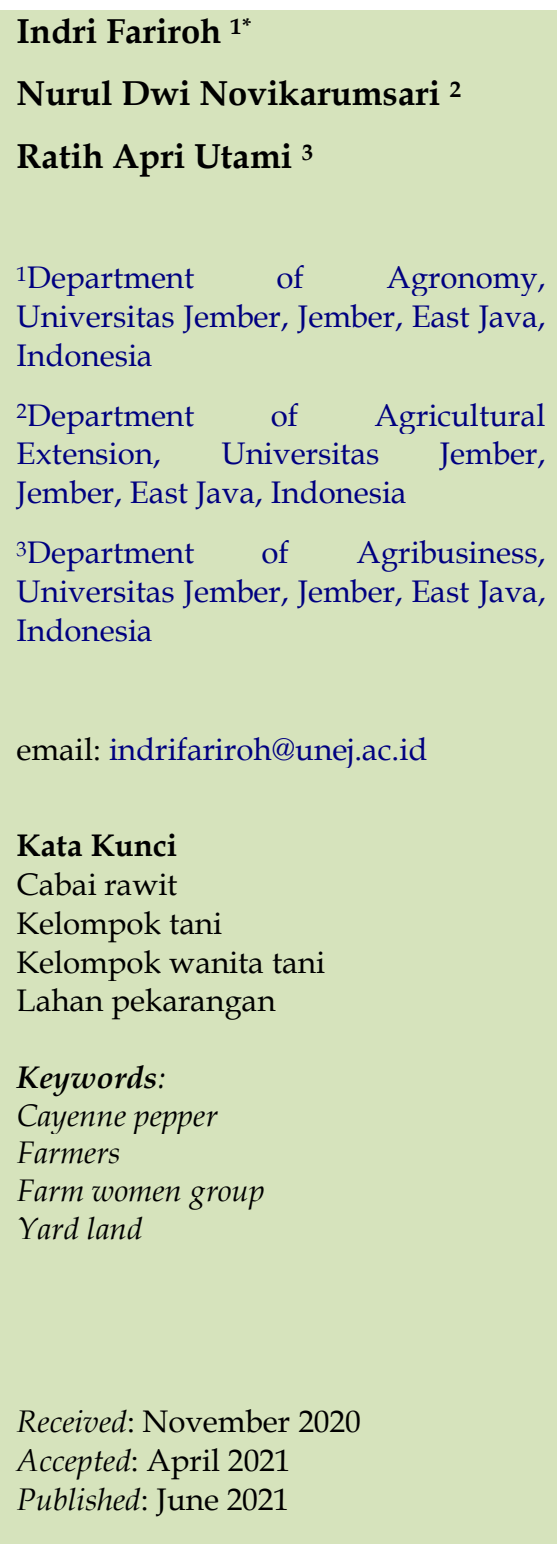

\begin{abstract}
Abstrak
Kelompok Tani Hidayah Tani merupakan kelembagaan tani di Jember, Jawa Timur. Potensi produktivitas cabai rawit yang besar sekitar 523 ton, namun sebagian besar anggota Kelompok Tani masih memprioritaskan bercocok tanam dengan pola tanam padi-padi-palawija dan padi-paditembakau. Sementara itu, cabai rawit sebagai potensi lokal belum menjadi prioritas karena minimnya pengetahuan teknik tentang budidaya cabai rawit. Kelompok ini memiliki beberapa kebutuhan dalam hal pendampingan dan pemberdayaan ekonomi melalui kelembagaan kelompok tani. Melalui kelembagaan berbasis kelompok, petani dapat memperoleh penyuluhan dan pendampingan terkait budidaya cabai rawit secara terpadu dengan memanfaatkan lahan pekarangan. Kegiatan pengabdian dilakukan melalui Sosialisasi tentang program pengabdian, Melakukan pendampingan budidaya cabai rawit terpadu, Melakukan penyuluhan terkait penguatan kelembagaan kelompok tani, dan Monitoring dan evaluasi. Respon petani terhadap pelaksanaan program pendampingan yang menunjukkan bahwa persepsi peserta terhadap pelatihan teknik budidaya cabai rawit tergolong baik dan ibu-ibu sepakat akan adanya pembentukan Kelompok Wanita Tani.
\end{abstract}

\begin{abstract}
Hidayah Tani Farmers Group is a farmer's institution in Jember, East Java. The potential for large cayenne pepper productivity is around 523 tons, but most members of the Farmers Group still prioritize farming with ricerice-palawija and rice-rice-tobacco cropping patterns. Meanwhile, cayenne pepper as a local potential has not become a priority because of the lack of technical knowledge about cayenne pepper cultivation. This group has several needs in terms of assistance and economic empowerment through farmer group institutions. Through group-based institutions, farmers can get counseling and assistance related to the cultivation of cayenne pepper in an integrated manner by utilizing their yards. Service activities are carried out through socialization of service programs, providing integrated cayenne pepper cultivation assistance, conducting counseling related to institutional strengthening of farmer groups, and monitoring and evaluation. Farmers' responses to the implementation of the mentoring program showed that the participants' perception of the cayenne pepper cultivation technique was good, and the women agreed that there would be a Women Farmers Group formed.
\end{abstract}

(C) 2021 Indri Fariroh, Nurul Dwi Novikarumsari, Ratih Apri Utami. Published by Institute for Research and Community Services Universitas Muhammadiyah Palangkaraya. This is Open Access article under the CC-BYSA License (http://creativecommons.org/licenses/by-sa/4.0/). DOI: https://doi.org/10.33084/pengabdianmu.v6i4.1843

\section{PENDAHULUAN}

Desa Sukowiryo Kecamatan Jelbuk Kabupaten Jember merupakan salah satu daerah yang sebagian besar penduduknya bermata pencaharian sebagai petani. Di daerah ini memiliki areal persawahan yang luas dan merupakan penghasil tanaman padi yang cukup besar. 
Selain itu, areal pekarangan yang cukup luas juga bisa dimanfaatkan berdasarkan potensi tanaman lokal daerah tersebut. Desa Sukowiryo Kecamatan Jelbuk memiliki potensi produktivitas cabai rawit sebesar 523 ton. Potensi produktivitas cabai rawit selain bisa ditanam di areal persawahan, juga bisa dimanfaatkan untuk penanaman di lahan pekarangan. Dalam hal kegiatan usahatani, masyarakat Desa Sukowiryo memiliki beberapa kebutuhan dalam hal pendampingan dan pemberdayaan ekonomi melalui kelembagaan kelompok tani yang bernama Kelompok Hidayah Tani. Sekretariat Kelompok Hidayah Tani bertempat di Dusun Sudung Barat, RT 003/RW 007, Desa Sukowiryo, Kecamatan Jelbuk, Kabupaten Jember. Sebagian besar anggota Kelompok Hidayah Tani bercocok tanam dengan pola tanam padi-padi-palawija dan padi-paditembakau. Sedangkan untuk tanaman cabai rawit sebagai potensi lokal, belum menjadi pengusahaan Kelompok Hidayah Tani dikarenakan kurangnya pengetahuan teknik dalam budidaya cabai rawit. Kelompok Hidayah Tani sampai saat ini memiliki beberapa kebutuhan dalam hal pendampingan dan pemberdayaan wanita tani yaitu perlu adanya pembentukan kelompok wanita tani. Melalui kelembagaan berbasis kelompok, petani dapat memperoleh penyuluhan dan pendampingan terkait budidaya cabai rawit secara terpadu dengan memanfaatkan lahan pekarangan sekaligus juga melakukan pemberdayaan bagi wanita tani dalam hal peningkatan nilai tambah dan pendapatan keluarga tani. Pengabdian ini bertujuan mengatasi permasalahan kurangnya pengetahuan Kelompok Hidayah Tani tentang budidaya teknik pengelolaan tanaman terpadu yaitu dengan memanfaatkan potensi lokal komoditas cabai rawit selain komoditas utama padi dan palawija. Sehingga perlu adanya pendampingan dan pelatihan teknik mengenai Pengelolaan tanaman terpadu dan pengendalian Organisme Pengganggu Tanaman (OPT). Sistem usaha tani terpadu selain dapat memperluas sumber pendapatan juga merupakan strategi untuk mengurangi risiko kegagalan usaha, serta penguatan kelembagaan melalui inisiasi Kelompok Wanita tani (Hastuty, 2013).

Produktivitas cabai rawit dapat ditunjang dengan tersedianya lahan pekarangan yang luas di sekitar rumah penduduk anggota kelompok tani menggunakan polybag. Kusumiyati et al. (2019) menjelaskan bahwa penggunaan metode polybag untuk budidaya cabai rawit di lahan pekarangan penduduk Desa Cileles, Kecamatan Jatinangor lebih disukai oleh 95.9\% responden, sementara penggunaan metode NFT yang dianggap lebih rumit dan membutuhkan biaya besar hanya diminati oleh $18.2 \%$ responden. Menurut Ashari et al. (2012), pemanfaatan lahan pekarangan umumnya bersifat sambilan atau mengisi waktu luang dan ditujukan untuk memenuhi gizi anggota keluarga serta sumber pendapatan tambahan bagi rumah tangga petani.

Selain itu, peningkatan produktivitas cabai rawit di lahan pekarangan desa Sukowiryo perlu didukung dengan penanganan OPT yang tepat. Upaya pengendalian OPT menggunakan keragaman hayati di lingkungan desa merupakan salah satu strategi yang diterapkan dalam pengelolaan tanaman terpadu. Edukasi dan sosialisasi tentang manfaat tanaman refugia sebagai pengendali OPT pada tanaman cabai sudah diterapkan oleh Septariani et al. (2019) di mitra Majelis Taklim Nailul Hidayah, Bantul. Tanaman refugia yang sudah dimanfaatkan adalah bunga kertas pink tumpuk (Zinnia elegans), bunga kertas pink, kuning, dan orange ( $\mathrm{Z}$. peruviana), bunga kenikir kuning dan orange (Cosmos caudatus), bunga matahari (Helianthus annuus), bunga jengger ayam (Celosia cristata), bunga jengger ayam kipas kuning dan merah (Celosia plumosa). 
Salah satu permasalahan dalam pengelolaan sumberdaya pertanian adalah masalah kelembagaan pertanian yang tidak mendukung yaitu kelembagaan di tingkat petani. Kelembagaan petani yang dimaksud di sini adalah lembaga petani yang berada pada kawasan lokalitas (local institution), yang berupa organisasi keanggotaan (membership organization) atau kerjasama (cooperatives) yaitu petani-petani yang tergabung dalam kelompok kerjasama (Uphoff, 1986).

Kelompok Hidayah Tani belum memiliki sistem kelembagaan yang kuat sehingga perlu inisiasi pembentukan Kelompok Wanita Tani (KWT) untuk mendukung potensi pertanian yang besar di Desa Sukowiryo. Kelompok Wanita Tani pada hakikatnya adalah bentuk pemberdayaan perempuan, dimana dimaksudkan sebagai upaya peningkatan kemampuan wanita dalam mengembangkan kapasitas dan ketrampilannya untuk meraih akses dan penguasaan terhadap, antara lain: posisi pengambil keputusan, sumber-sumber, dan struktur atau jalur penunjang. Pemberdayaan wanita dapat dilakukan melalui proses penyadartahuan sehingga diharapkan wanita mampu menganalisis secara kritis situasi masyarakat dan dapat memahami praktek-praktek diskriminatif yang merupakan kosntruksi sosial (Aslichati, 2011). Melalui kelembagaan berbasis kelompok ini, petani dapat memperoleh penyuluhan dan pendampingan terkait budidaya cabai rawit secara terpadu dengan memanfaatkan lahan pekarangan.

\section{METODOLOGI}

Program pengabdian dilakukan pada 18 September - 18 Desember 2020, berfokus pada peningkatan penyuluhan dan pendampingan budidaya cabai rawit di Kelompok Hidayah Tani, dilakukan melalui langkah berikut:

1. Sosialisasi tentang program pengabdian
2. Melakukan pendampingan budidaya cabai rawit terpadu

3. Melakukan penyuluhan terkait penguatan kelembagaan kelompok tani

4. Monitoring dan evaluasi

Kelompok sasaran kegiatan adalah Kelompok Hidayah Tani Desa Sukowiryo, Kecamatan Jelbuk, Kabupaten Jember yang masih memerlukan pendampingan dalam rangka penguatan kelembagaan dan pendampingan teknik Pengelolaan Tanaman Terpadu (PTT) kelompok tani yang memiliki potensi lokal berupa komoditas cabai rawit. Pendekatan kelembagaan yang dilakukan melalui pola Co-operative in action, diharapkan mampu menginventarisasi seluruh aspek usaha dari pengembangan pola pikir anggota kelompok, penyediaan sarana dan peralatan, penguatan manajemen budidaya melalui penyuluhan, pelatihan dan pendampingan berbasis kelompok.

\section{HASIL DAN PEMBAHASAN}

\section{Sosialiasi tentang program pengabdian}

Kegiatan sosialisasi tentang program pengabdian dilaksanakan dua minggu sebelum pelaksanaan penyuluhan dan pelatihan teknik budidaya cabai rawit oleh tim pengabdian. Sosialisasi dilakukan dengan pemberian arahan tentang tujuan program pengabdian serta teknik pelaksanaan.

Penyuluhan dan pelatihan teknik budidaya cabai rawit terpadu Penyuluhan dilakukan oleh tim pengabdian dan Dinas Pertanian Kabupaten Jember. Kegiatan dimulai dengan pemberian arahan tentang teknik budidaya cabai rawit dan pelatihan persiapan bibit cabai rawit untuk optimalisasi lahan pekarangan didampingi oleh tim pengabdian dari Fakultas Pertanian Universitas Jember. Lahan pekarangan di sekitar rumah petani di Desa Jelbuk cukup luas sehingga bisa dimanfaatkan untuk pembibitan cabai rawit dengan polybag. 
Hasil panen cabai rawit yang tumbuh di pekarangan diharapkan dapat memenuhi kebutuhan rumah tangga petani terutama di masa pandemi covid-19. Selain itu, hasil panen cabai rawit yang melimpah bisa menjadi sumber pendapatan petani melalui penjualan hasil panen di pasar lokal. Manfaat pengelolaan pekarangan dalam ketahanan pangan ditegaskan oleh Nurwati et al. (2015) dimana pengelolaan pekarangan yang baik berfungsi sebagai apotik hidup, warung hidup, lumbung hidup serta memperindah halaman rumah.

Selain penyuluhan tentang pemanfaatan pekarangan rumah melalui budidaya cabai rawit, kelompok tani juga dikenalkan tentang pengelolaan tanaman terpadu. Varietas cabai rawit yang digunakan adalah cabai rawit BARA-F1 yang merupakan cabai rawit lokal nonhibrida. Varietas ini mempunyai karakter tahan (medium) layu bakteri yang disebabkan oleh Pseudomonas solanacearum (Direktorat Perbenihan Hortikultura Kementerian Pertanian Republik Indonesia, 1999) sehingga mendukung pengelolaan tanaman terpadu.

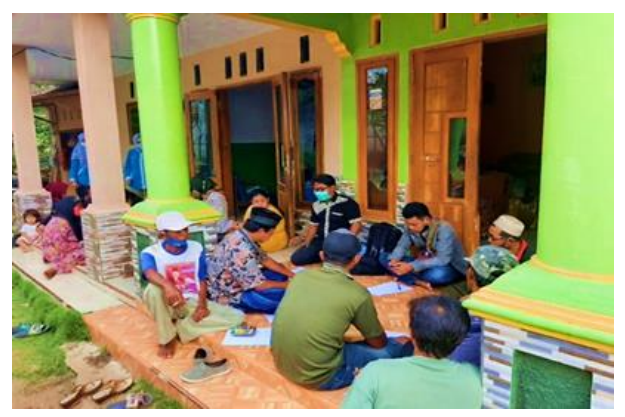

Gambar 1. Arahan Tentang Teknik Budidaya Cabai Rawit

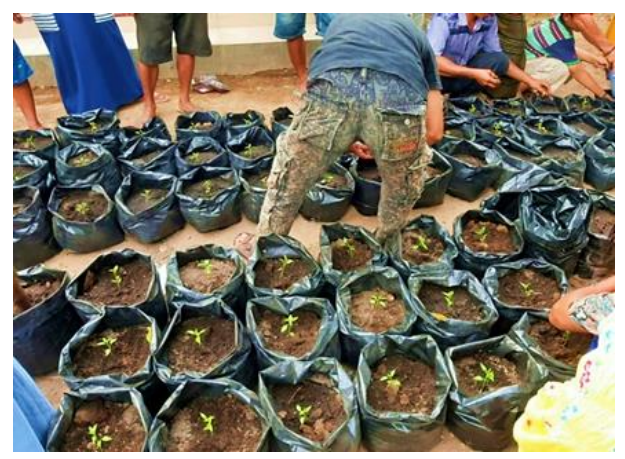

Gambar 2. Persiapan Bibit Cabai Rawit untuk Optimalisasi Lahan Pekarangan
Selanjutnya penyampaian materi tentang pengelolaan OPT terpadu disampaikan Petugas Pengendali Organisme Tumbuhan (POPT) dengan mengenalkan petunjuk teknik pembuatan pestisida nabati sederhana dari empon-empon dan daun sirsak. Hartini dan Yahdi (2015) menjelaskan bahwa ekstrak daun sirsak memiliki potensi sebagai insektisida kutu daun persik dengan efektivitas sebesar 100\% pada konsentrasi 8 dan 10\%. Pengelolaan OPT secara terpadu dikenalkan kepada Kelompok Hidayah Tani dengan harapan bisa mengurangi penggunaan pestisida kimia yang tidak ramah lingkungan.

Terdapat dua materi pembuatan pestisida nabati, yaitu resep pertama berbahan dasar utama empon-empon dan resep kedua menggunakan daun sirsak. Pembuatan pestisida nabati yang disampaikan dengan bahan utama empon-empon terdiri dari masing-masing $1 \mathrm{~kg}$ bawang putih, kunyit, laos, jahe, 30 batang serai, 100 g merica, dan 5 sendok teh sabun colek. Semua bahan ditumbuk dan dicampur dengan $10 \mathrm{~L}$ air dan didiamkan selama 24 jam. Setelah 24 jam, larutan ditambah sabun colek dan diaduk rata, kemudian disaring. Dosis penyemprotannya adalah $0.5 \mathrm{~L}$ larutan yang diencerkan dalam $15 \mathrm{~L}$ air.

Pestisida nabati ini efektif digunakan untuk mengendalikan lalat buah, ulat daun, dan aphids pada tanaman cabai. Salah satu komposisi pestisida nabati resep pertama adalah batang serai. Menurut Arfianto (2016), aplikasi penyemprotan pestisida organik ekstrak serai wangi dengan konsentrasi 25-75 $\mathrm{ml}$ ditambah air bersih $100 \mathrm{ml}$ mulai berpengaruh terhadap populasi hama kutu daun cokelat di minggu kedua hingga minggu ketiga pada tanaman cabai. Tanaman serai wangi mengandung senyawa citronella yang merupakan racun kontak dan menyebabkan serangga yang terkena mengalami kekurangan cairan. Selain itu, serangga jenis kutu daun tidak menyukai bau dari ekstrak serai wangi. 


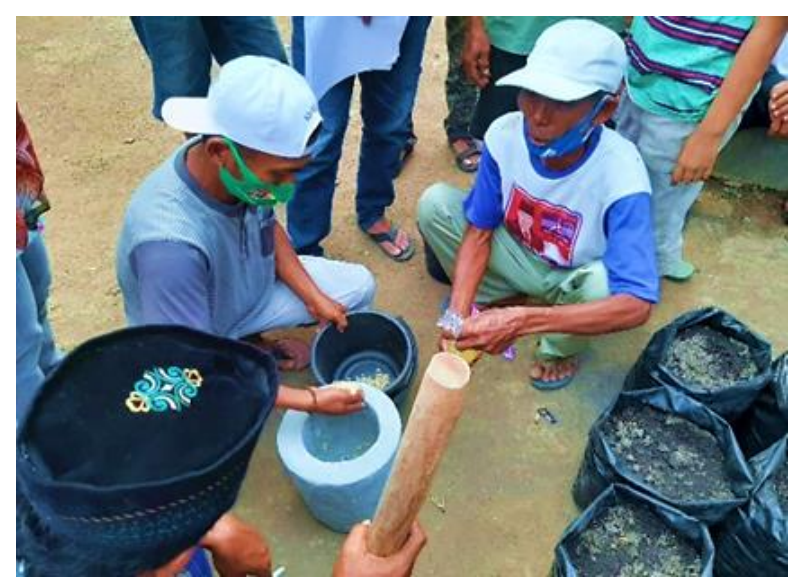

Gambar 3. Pelatihan Teknik Pembuatan Pestisida Nabati

Pestisida nabati resep kedua menggunakan 110 lembar daun sirsak, $1 \mathrm{~kg}$ daun pahitan, $1 \mathrm{~kg}$ kunyit, $10 \mathrm{sdm}$ kapur, dan 30 L air sebagai bahan utamanya. Daun sirsak, daun pahitan dan kunyit kemudian ditumbuk halus dan ditambahkan $30 \mathrm{~L}$ air. Larutan ditambahkan kapur, disimpan selama 24 jam, dan disaring ketika akan diaplikasikan. Dosis pemakaian larutan pestisida nabati adalah perbandingan $1 \mathrm{~L}$ larutan : $10 \mathrm{~L}$ air. Umumnya digunakan untuk mengendalikan OPT cabai dari jenis serangga. Bahan utama pembuatan pestisida nabati resep kedua adalah daun sirsak. Herdiyanti et al. (2019) menguji efektivitas beberapa konsentrasi esktrak daun sirsak dalam mengendalikan hama kutu daun persik (Myzus persicae Sulz.) di tanaman cabai rawit. Hasil penelitian menunjukkan bahwa dosis ekstrak daun sirsak $10-12 \%$ terbukti efektif dalam mematikan hama kutu daun dengan jumlah rata-rata kematian 5 individu.

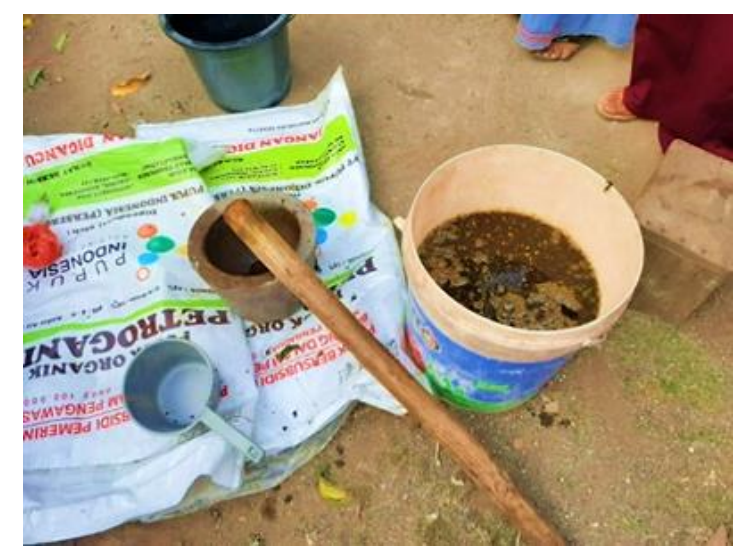

Gambar 4. Larutan Pestisida Nabati Resep Kedua yang Sudah Jadi
Pengendalian OPT di tanaman cabai rawit terutama yang disebabkan oleh busuk bakteri dan busuk buah Antraknosa dapat dikendalikan dengan pestisida nabati sederhana resep ketiga sesuai arahan dari POPT. Komposisinya terdiri dari $1 \mathrm{~kg}$ bawang putih, $0.5 \mathrm{~kg}$ minyak sayur, $0.1 \mathrm{~kg}$ sabun colek, dan $10 \mathrm{~L}$ air. Bawang putih ditumbuk sampai halus, kemudian ditambahkan minyak sayur dan disimpan selama 24 jam. Setelah diinkubasi selama 24 jam, larutan ditambahkan air dan sabun colek kemudian disaring. Dosis aplikasi yang digunakan adalah $1 \mathrm{~L}$ larutan : $10 \mathrm{~L}$ air. Pengaplikasian larutan pestisida nabati bisa dengan disemprotkan ke tanaman yang terserang penyakit atau disiramkan di sekitar perakaran tanaman.

Salah satu komposisi pestisida nabati resep ketiga adalah bawang putih. Zulkipli et al. (2018) menyatakan bahwa intensitas serangan penyakit antraknosa pada cabai menggunakan ekstrak larutan daun sirih sebesar 0.31, daun sirsak 0.33 , bawang putih 0.35 , daun pepaya 0.39 . Sehingga dapat dikatakan bahwa ekstrak bawang putih berpotensi mengendalikan serangan antraknosa pada tanaman cabai. Sopialena et al. (2020) menambahkan bahwa penggunaan bawang putih menjadi salah satu alternatif pestisida nabati dalam menghambat koloni Colletotrichum capsici Sydow penyebab antraknosa buah cabai yang ditandai dengan mengecilnya diameter isolat C. capsici $(5.74 \mathrm{~cm})$ jika dibandingkan dengan kontrol $(8.72 \mathrm{~cm})$ di hari kelima inkubasi.

\section{Penyuluhan terkait penguatan kelembagaan kelompok tani}

Penyuluhan terkait kelembagaan dilakukan dengan penyampaian materi dan workplay di kelompok Hidayah Tani untuk memperkuat kerjasama dalam kelompok serta membentuk inisiasi keterlibatan para ibu-ibu dalam membentuk kelompok wanita tani untuk mendukung potensi budidaya cabai rawit di lahan pekarangan. Kegiatan penyuluhan penguatan kelembagan kelompok tani diawali dengan penjelasan 
tentang maksud dan tujuan pembentukan KWT dan simulasi melalui permainan menggunakan kertas flipchart untuk mengetahui sejauh mana minat wanita tani dan ibu-ibu terhadap pembentukan kelompok wanita tani. Dari hasil pelibatan mereka dalam menyampaikan dan menuliskan pendapat pada berbagai simulasi menggunakan flipchart, untuk mengetahui kesadaran ibu-ibu dalam pembentukan KWT dapat diketahui bahwa ibu-ibu sepakat akan adanya pembentukan KWT. Selanjutnya mereka menuliskan keinginan untuk bergabung di KWT karena untuk menambah kegiatan, menambah pengalaman menanam cabai, menambah penghasilan dan supaya lebih maju kelompok taninya. Sedangkan keberlanjutan kegiatan KWT mereka ingin diadakan pelatihan penanaman cabai, tomat, timun beserta dengan pemasaran dan pengolahannya.

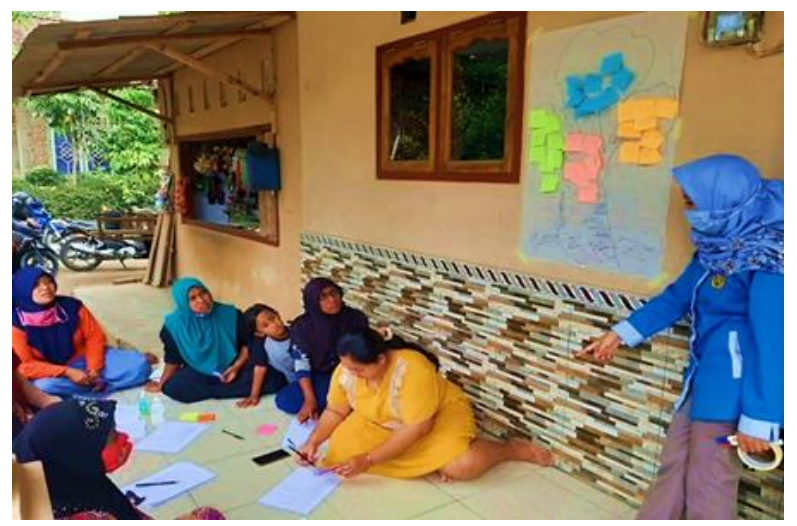

Gambar 5. Penyuluhan penguatan kelembagaan melalui Inisiasi pembentukan KWT

Kelompok Wanita Tani dibentuk sebagai upaya pelibatan wanita tani dan ibu-ibu secara langsung dalam usaha-usaha peningkatan hasil pertanian. Harapan dari inisiasi pembentukan KWT pada Kelompok Hidayah Tani Desa Sukowiryo ini dapat menjadi wadah bagi anggotanya untuk menyalurkan keterampilan dalam bidang pertanian dan dapat dijadikan sebagai sarana pertumbuhan ekonomi bagi para anggotanya serta menjadi bagian dari motivator dalam adopsi dan pengenalan teknologi pertanian. Berdasarkan Yaro
(2013), penerimaan, perbedaan pengetahuan, pengalaman petani akan memengaruhi penerimaan petani dalam proyek kedepannya termasuk pembentukan KWT.

\section{Monitoring dan Evaluasi}

Evaluasi keberhasilan pengabdian dilakukan setelah proses pengabdian pada Kelompok Tani Hidayah Tani Desa Sukowiryo, Kecamatan Jelbuk, Kabupaten Jember. Proses evaluasi dilakukan dengan menggunakan berbagai instrumen, diantaranya; lembar observasi pelaksanaan kegiatan dan angket respon petani yang dilakukan pendampingan. Lembar observasi kegiatan digunakan untuk mengetahui terlaksananya pendampingan sesuai dengan tujuan yang ingin dicapai. Sedangkan angket respon peserta untuk mengetahui respon petani terhadap pelaksanaan program pendampingan yang menunjukkan bahwa persepsi peserta terhadap pelatihan teknik budidaya cabai rawit tergolong baik.

\section{KESIMPULAN}

Adapun kesimpulan setelah dilaksanakan kegiatan pengabdian ini yaitu potensi lokal komoditas cabai rawit yang ada di Desa Sukowiryo, Kecamatan Jelbuk dapat dioptimalkan melalui pendampingan teknik dengan tujuan meningkatkan produksi dan mengurangi penggunaan pestisida kimia yaitu melalui sistem PTT. Teknik Budidaya Cabai Rawit dengan Pendekatan Pengelolaan Tanaman Terpadu melalui tahap: Persemaian, Penyiapan Lahan dan Penanaman, Pemeliharaan, Pengendalian OPT, Panen dan Pasca Panen. Pendampingan dilakukan secara intensif oleh tim PkM dan peran penyuluh dalam meningkatkan partisipasi anggota kelompok untuk mengikuti pelatihan dan bimbingan teknik pengelolaan tanaman terpadu pada komoditas tanaman cabai rawit sehingga melalui kelembagaan berbasis kelompok, diharapkan 
dapat memperoleh penyuluhan dan pendampingan terkait budidaya cabai rawit secara terpadu dengan memanfaatkan lahan pekarangan. Kelompok Wanita Tani dibentuk sebagai upaya pelibatan wanita tani dan ibu-ibu secara langsung dalam usaha-usaha peningkatan hasil pertanian. Dari hasil pelibatan mereka dalam menyampaikan dan menuliskan pendapat dapat diketahui bahwa ibu-ibu sepakat akan adanya pembentukan KWT. Selanjutnya mereka menuliskan keinginan untuk bergabung di KWT karena untuk menambah kegiatan, menambah pengalaman menanam cabai, menambah penghasilan dan supaya lebih maju kelompok taninya. Sedangkan keberlanjutan kegiatan KWT mereka ingin diadakan pelatihan penanaman cabai, tomat, timun beserta dengan pemasaran dan pengolahannya. Kedepannya dari inisiasi pembentukan KWT pada Kelompok Hidayah Tani Desa Sukowiryo ini dapat menjadi wadah bagi anggotanya untuk menyalurkan keterampilan dalam bidang pertanian dan dapat dijadikan sebagai sarana pertumbuhan ekonomi bagi para anggotanya serta menjadi bagian dari motivator dalam adopsi dan pengenalan teknologi tani.

\section{UCAPAN TERIMA KASIH}

Terima kasih kepada LP2M Universitas Jember atas Dana DIPA Universitas Jember untuk Hibah Pengabdian Dosen Pemula sehingga program pengabdian ini dapat terselenggara dengan lancar.

\section{REFERENSI}

Arfianto, F. 2016. Pengendalian Hama Kutu Daun Coklat pada Tanaman Cabe mengggunakan Pestisida Organik Ekstrak Serai Wangi. Anterior Jurnal. 16(1):57-66. https://doi.org/10.33084/anterior.v16i1.78

Aslichati, L. 2011. Organisasi Pemberdayaan Dan Kesejahteraan Keluarga Sebagai Sarana
Pemberdayaan Perempuan. Jurnal Organisasi dan Manajemen. 7(1):1-7.

Ashari, Saptana, Purwantini, T.B. 2012. Potensi Dan Prospek Pemanfaatan Lahan Pekarangan Untuk Mendukung Ketahanan Pangan. Forum Penelitian Agro Ekonomi. 30(1):13-30. http://dx.doi.org/10.21082/fae.v30n1.2012.1 3-30

Direktorat Perbenihan Hortikultura Kementerian Pertanian Republik Indonesia. 1999. Deskripsi Cabai Rawit Varietas Bara, Lampiran Keputusan Menteri Pertanian Nomor: 874/Kpts/TP.240/7/1999 tanggal 28 Juli 1999. Direktorat Perbenihan dan Sarana Produksi.

Hartini, F., Yahdi, Y. 2015. Potensi Ekstrak Daun Sirsak (Annona muricata, L.) Sebagai Insektisida Kutu Daun Persik (Myzus persicae, Sulz) pada Daun Tanaman Cabai Rawit (Capsicum frutescens). Biota: Biologi dan Pendidikan Biologi. 8(1):107-116.

https://doi.org/10.20414/jb.v8i1.63

Hastuty, S. 2013. Pola Usahatani Terpadu dalam Upaya Pengembangan Agribisnis di Kecamatan Bara Kota Palopo. Dinamika: Jurnal Matematika dan Ilmu Pengetahuan Alam (Journal of Mathematics and Natural Sciences). 4(1):1-14.

Herdiyanti, H., Suryana, S., Suhaina, S., Afromika, D. 2019. Uji Efektifitas Pestisida Nabati Daun Sirsak (Annona muricata L.) terhadap Mortalitas Hama Tanaman Cabai Rawit (Capsicum frustescens L.) serta Kajiannya sebagai Sumber Belajar Biologi. Biopedagogia. 1(1):34-40.

https://doi.org/10.35334/biopedagogia.v1i1. 1696

Kusumiyati, K., Sutari, W., Farida, F. 2019. Pemanfaatan Lahan Pekarangan Rumah Untuk Budidaya Tanaman Cabai Rawit Secara Hidroponik. Jurnal Pengabdian Kepada Masyarakat. 3(4):90-93.

Nurwati, N., Surtinah, S., Masykur, A. 2015. Analisis Pemanfaatan Pekarangan untuk Mendukung Ketahanan Pangan di Kecamatan Rumbai Pesisir Kota Pekanbaru. Jurnal Ilmiah Pertanian. 11(2):1-8. https://doi.org/10.31849/jip.v11i2.1259

Septariani, D.N., Herawati, A., Mujiyo, M. 2019. Pemanfaatan Berbagai Tanaman Refugia Sebagai Pengendali Hama Alami Pada 
Tanaman Cabai (Capsicum annum L.). Prima: Journal of Community Empowering and Services. 3(1):1-9.

https://doi.org/10.20961/prima.v3i1.36106

Sopialena, S., Mirza, M.A., Soraya, R. 2020. Influence of Biopesticides on Gowth (Colletotrichum capsici Sydow) Causes Antraknosa in Cayenne Pepper (Capsicum frutescens L.). Jurnal Agroekoteknologi Tropika Lembab. 2(2):105110.

http://dx.doi.org/10.35941/jatl.2.2.2020.3222. 105-110

Uphoff, N. 1986. Local Institutions and Participation for Sustainable Development. London: International Institute for Environment and Development.

Yaro, J.A. 2013. The perception of and adaptation to climate variability/change in Ghana by smallscale and commercial farmers. Regional Environmental Change. 13:1259-1272. https://doi.org/10.1007/s10113-013-0443-5

Zulkipli, S., Marsuni, Y., Rosa, H.O. 2018. Uji Lapangan Beberapa Pestisida Nabati untuk Menekan Perkembangan Penyakit Antraknosa pada Tanaman Cabai Besar. Jurnal Proteksi Tanaman Tropika. 1(2):32-34. 